\title{
Carbonatic builds prognosing by method seismic inversion
}

*Borodulin E. M. (SGC "Ukrgeofizyka", Pridneprovskaja Geophisical Exploration Expedition)

\section{SUMMARY}

Some practical aspects of impedance sections construction on the base of seismic inversion are discused on the example of standart seismic and well log data. As the object of inversion was taken the carbonatic builds within Zapadno-Olhovsky area. The main attention is paid to technological aspects of inversion, impedance sections and analysis of the data. The materials obtained permit highly appreciate the practical usefulness of seismic inversion.

\section{Прогнозування рифогенних утворень методом сейсмічної}

iнверсіi

*Бородулін Є. М. (ДГП "Укргеофізика" Придніпровська геофізична розвідувальна експедиція)

Прогнозирование рифогенных образований методом

сейсмической инверсии

*Бородулин Е. М. (ГГП "Укргеофизика", Приднепровская геофизическая разведочная экспедииия) 